\title{
PLOTTING A PATH FOR LATER STEPS: TUNING IN WITH NÚÑEZ, RANCIÈRE, AND SOLOGUB
}

Franc Chamberlain

\section{ONE}

Nicolás Núñez and the Taller de Investigación Teatral have developed a series of immersive or participatory structures and scores to transport participants into an imaginal realm where they have the possibility to slough off their everyday selves and safely enter altered, ecstatic, states of awareness. As the main body of Anthropocosmic Theatre articulates, these practices were developed through a range of encounters with different lineages including Tibetan Buddhism, Stanislavskian actor-training, Grotowski's post-theatrical actions, and an embodied reconnection with a pre-Hispanic, Nahuatlan, current.

Does this mean that participants in the performances and trainings of the Taller lose touch with their embodied reality? Not at all: the practices are designed to assist participants to transform their relationship to reality through progression along a vertical axis from everyday life up through epic/ mythic, theistic, and ritualistic levels with the aim of reaching the level of 'pure undifferentiated energy' (Morris, 2017: 173). Without a grounding in the actual practices involved, this can easily sound like a process of spiritual ascent and disembodiment; absconding from material reality into a realm of dreams and fictions and progressively losing touch with our body. The Taller's work, however, aims at synchronising body and mind with the intention of enabling individuals to 'have the energy and the courage to maintain [themselves] in the living instant' (Núñez, p.277 below). The journey is an embodied one which requires an intense psychophysical commitment from the participant, a willingness to generate the energy to attempt a leap to the next level. Each leap, if successful, offers another perspective on our lives, our relationships and the world but, I would suggest, that this perspective isn't 
one of 'looking down' on our previous view but of 'opening out' to a wider experiencing of self, other and environment (or cosmos).

Ultimately, 'pure undifferentiated energy', the term used by Morris, stands in for a core element of Nabua metaphysics, that of teotl a process of perpetual generation and regeneration which we might also consider an ongoing creative and autopoetic process of becoming (Maffie, IEP n.d,). Teotl manifests in complementary polarities and is in that way superficially similar to the Chinese idea of the ten thousand things being generated by the complementary opposites of yin and yang emerging from the dao. Everything is, in some way, teotl, including people, and the direction of development in the Taller's processes would be for the participants to become more fully themselves and more in tune with others and the cosmos. It would seem that becoming attuned to pure undifferentiated energy does not involve the loss of differentiation but is an awareness of the vital energy that is present in all processes of becoming.

That one becomes 'more fully oneself' and more 'in tune with the cosmos' seems a rather big claim to make, particularly if we imagine that participants in one of the Taller's performances might only be with the group for a couple of hours at most. Indeed, Núñez doesn't make the claim that these changes will happen. In his introduction to the performance of Cura de espantos in Huddersfield in 1999, for example, he explicitly stated that 'some of us may get something...some of us not' (Chamberlain in Yarrow et al 2007: 178). Without adequate context this could be read in a judgmental way implying that only the 'worthy' will 'get something' and those who don't 'get' anything, who don't feel themselves to be more 'fully themselves' or 'more in tune with the cosmos', have somehow failed. But this would be the logic of a cult not of a Theatre Research Studio, and Núñez and his 'gang' are explorers, inviting participants to carry out their own research to see what happens. Maybe we get something today, maybe not. It's possible that we might become aware of how distant we are from ourselves and others or how disconnected from the environment we feel. Paradoxically, perhaps, that would a good outcome 
as we would have become more aware of our situation; a discovery that is potentially disturbing but which still offers the opportunity for creative development.

The Taller's work has strong affinities with Grotowski's Art as Vehicle or Ritual Arts, an 'attempt to create a performative structure that functions as a tool for work on oneself' (Slowiak and Cuesta, 2018: 53). Such a structure (or score) would enable 'energy transformation' from coarse to subtle by working on the body, heart and head of the participant (Slowiak and Cuesta, 2018: 53; Grotowski, 1995: 122).43

\section{TWO}

Núñez and the Taller de Investigacion Teatral are firmly situated within the tradition of theatre laboratories that began in 1905 in Russia with Stanislavski's first experiment in setting up a theatre laboratory. This laboratory (or studio), led by Meyerhold, focused on problems in staging symbolist dramas such as Maeterlinck's The Death of Tintagiles. For a variety of reasons, including the artistic differences and the impact of the 1905 Revolution, this first experimental studio was short-lived but, in 1912, Stanislavski set up the First Studio which became established as a key component of the Moscow Art Theatre and stimulated the creation of theatre laboratories throughout the world.

As Schino points out, however, theatre laboratories are 'not a genre or a uniform category' (2009: 7) and terms such as theatre laboratory, studio, workshop, atelier, or taller are neither fully interchangeable nor precise translations of each other. Whilst this is important to bear in mind, there are also similarities that can be identified and Chemi refers to a 'laboratory turn' in the theatre, asserts that the First Studio of the Moscow Art Theatre can, indeed, be defined as a theatre laboratory, and articulates the key characteristics of such laboratories as a 'sustained, free and explorative mindset with the awareness of and commitment to a research programme' (Chemi, 2018: 5).

43 The notion of transformation of energy from coarse to subtle is also mentioned by Cassiano Sydow Quillici (pp. 187 - 188) and Middleton (pp. 234 - 235). 
A laboratory's research may create public performances but the work is not driven by a production schedule. As Stanislavski noted:

Laboratory work cannot be done in the theatre itself, with its daily performances, its concerns over the budget and the box office, its heavy artistic commitments and the practical difficulties of a large enterprise (Chemi, 2018: 5; Schino, 2009: 101; Stanislavski, 2008: 301).

Theatre laboratories, as Stanislavski suggests, need to be free from the demands of both the market and the public. This requires access to either private or public funding and a building where artistic research can be carried out with few strings attached. It would be expected that the some of the work would be shared and that the experimentation would further our understanding of the theatre. Grotowski's Theatre Laboratory was funded by the communist regime in Poland, for example, and the government in the Soviet Union had earlier funded a number of studios after the 1917 Revolution. Universities were also places where a theatre laboratory might be established and allowed to conduct research free from the demands of the market and Núñez and the Taller were able to secure a base at UNAM in Mexico City in 1975 and have remained there ever since.

One aspect of the theatre laboratories, including those of Stanislavski, Grotowski, and Núñez that is perhaps less often noted than it could be is that they aim to create sacred spaces with an atmosphere which would demand a different level of attention from participants and engender a quality of experience which was markedly different from their daily lives. Stanislavski and Sulerzhitsky imagined developing a 'spiritual order of actors' (1980: 537) and the Theatre Studio was their laboratory in which these experiments could be carried out.

Stanislavski had set up the Studio partly because he had struggled to find a way to stage the plays of Maeterlinck - a problem he shared with others in Europe at the time. August Strindberg, for example, had struggled with the plays of Maeterlinck and debated whether or not to include them in the programme of his Intimate Theatre in 1908 before deciding that it 
was best to avoid them. A key problem, for Strindberg, was the absence of actors who had the ability to 'gain entrance into this poet's marvellous world' (1967: 301). This ability, according to Strindberg, could only be acquired by passing through what he called the Inferno, a disturbing, but ultimately transformational process, that he'd experienced in his own life prior to writing his most innovative works such as To Damascus, A Dream Play and The Ghost Sonata. Strindberg, however, lacked any training programme that would enable the development of the kind of actor he felt was necessary in order to stage Maeterlinck.

The idea of an actor being transformed through an inferno experience is implicit in Artaud's image of actors as being 'like victims burnt at the stake, signalling through the flames' (Artaud, 1958: 13) and Grotowski believed that this image contains the 'whole problem of spontaneity and discipline' in the theatre (2002: 125). The high intensity of energy contained in the image of the actor burning is matched by the discipline and precision needed to shape the signals effectively and these aspects of high intensity and precision are also present in the work of the Taller de Investigacion Teatral.

The initial focus of Stanislavski, Strindberg and Artaud was on the training of the actor to stage plays and the audience would still be separate from the doers. Artaud imagined different configurations of the theatre space to adjust the relationship between actors and spectators but the two roles were left untouched: actors were doers and spectators watched what was done (even if the aim was to cross that boundary with an affective athleticism which infected the audience). In Grotowski's work on productions prior to the mid1970s there was also an attempt to use an altered spatial relationship to effect a change in the spectators themselves. In his paratheatrical experiments (19731978) Grotowski sought to abolish the distance between actor and spectator in order to open up a space of collective creativity where participants were able to drop their habitual behaviours and discover new ways of relating to themselves and each other. Ultimately he was unconvinced of the viability of this approach and moved on to explore techniques from a range of cultures 
that were designed to have precise effects on participants and had a long history of doing so. This period of exploration was known as the Theatre of Sources and it is during this period that Núñez and his colleagues collaborated with Grotowski (see Middleton and Núñez, 2018).

\section{THREE}

The possibility of turning spectators into active participants was not something unique to Grotowski or Núñez, of course, and Rancière sees the aim to transform the spectator from 'passive voyeur' to 'active participant' (2011: 4) as a defining aspect of theatrical reform since the early part of the twentieth century. This process of transformation has two different goals which are sometimes complementary and sometimes in conflict. One aim is to transform the spectator into a 'scientific investigator or experimenter' (Rancière, 2011: 4) whilst the other is to transform her into a participant who is 'in possession of all her vital energies' (Rancière, 2011: 4). These two tendencies are represented by Brecht and Artaud respectively and it's possible to insert Grotowksi into this second lineage and, at least by association, Núnez and the Taller. What both approaches have in common, beyond the aim of transforming the spectator from a so-called passive into a so-called active position, is that they accept the idea that theatre is, in some sense, false - whether inherently or contingently. Spectators are captured by the illusions of theatre which render them passive; they are stupefied. If theatre is intrinsically false and disempowering then it would be necessary to move beyond theatre to effect a transformation, but if it is only contingently false then it is possible to use theatre as a way of questioning or analysing itself. In both lineages there is also a belief that theatre was once more than it is and can be so again. All of this is based on the commonly held notion that the spectator is passive and needs to be reconstructed by the performance and Rancière rightfully calls this notion into question.

Acknowledging that the reformers often return to the roots of the theatre in Ancient Athens, Rancière points to their desire to return to the theatre 
as the 'active body of a community enacting its living principle' (2011: 5). A century earlier the Cambridge anthropologist Jane Ellen Harrison wrote in her Ancient Art and Ritual that:

There is no division at first between actors and spectators; all are actors, all are doing the thing done, dancing the dance danced... No one at this stage thinks of building a theatre, a spectator place. It is in the common act, the common or collective emotion, that ritual starts. This must never be forgotten (Harrison, 1913: 126).

This return to ritual, or at least a reference to the theatre's ritual roots, runs throughout the past one hundred and fifty years. Five years before Harrison's book, in 1908, the same year as Strindberg decided that Maeterlinck's plays were 'unstageable', Fyodor Sologub, seeking to restore the ritual dimension to the theatre, wrote:

the rhythm of liberation is the rhythm of the dance [...] the dancing spectator both male and female will come to the theatre and at the threshold they will leave behind their crude petty bourgeois clothes, and race along in the light dance... So the crowd, which has come to look on, will be transformed in the round dance [...] (Sologub 1977: 99).

In Sologub's vision the spectators would no longer be separated from the action, passively watching, but involved in a round dance returning to the origins of the theatre in a resurrected mystical community. Sologub believed that we had lost the playful creativity that we had as children and, asking what we wanted from the theatre answered that it was the same thing that we wanted for our play when we were children: 'fiery ecstasy, ravishing the soul from the tight fetters of our boring and barren life' (1977: 88).

Sologub's vision wasn't actualised, and nor was the Mysterium of his younger, and even more visionary contemporary, Alexander Scriabin. The Mysterium would also have transformed spectators into participants who, at the end of a seven-day ritual in the Himalayas, would 'achieve spiritual unity with the divine cosmos' (Gawboy, 2015). 
Accessing the 'pure undifferentiated energy' that Morris and Núñez refer to sounds, at least superficially, akin to Scriabin's aim and the links between Sologub's vision and Harrison's archaeological assertion are evident. Influencing the thinking of both practitioners and theorist there is the current flowing from Nietzsche whose work had such a profound influence on the theatrical innovators of the twentieth century with his conceptualisation the twin forces of Apollo and Dionysos in The Birth of Tragedy (1872). These complementary opposites suggest the daoist pairings of yin and yang and the dynamic oppositions of teotl but Nietzsche's thought owes more to Schopenhauer's concept of the Will which is the force that propels all human activity and which he was later to reconceptualise as the Will to Power (Smith in Nietzsche, 2000: xxx). There can be a temptation to simply assume that the primordial source of these varied polarities is the same, that the names are simply nothing more than labels placed on identical phenomena. There is also the risk of assuming that the experiences of the individuals involved in these processes of transformation will be identical.

\section{FOUR}

Sologub wanted to break down the barriers between performer and spectator and restore a sense of community. Rancière claims that there is a 'presupposition that theatre is in and of itself communitarian' (2011: 16). But if this were the case then why would the reformers feel any need to transform the relationship between spectator and performer? Surely the visions of Sologub and Scriabin, or the practices of Grotowski and Núñez make the assumption that this communitarian aspect is either buried and needs to be uncovered, or needs to be created and the role between spectators and performers transformed. The theatre is a machine for making and transforming communities, but the transformations that it effects need not be identical in each circumstance. Nor is theatre only a machine for making and re-making communities. 
Rancière's concern is that by focusing on the communitarian dimension of the theatre those who wish to turn spectators into active participants not only undermine the importance of spectatorship for the theatre, but also forget that 'there are only ever individuals plotting their own paths in the forest of things, acts and signs that confront or surround them'(2011:16). Yet Rancière assumes that in any process of turning the spectator into a participant or of generating a temporary community, the aim is to erase the experience of the individual rather than to place the individual within a new set of circumstances or, at least, a set of circumstances that are different for those in which they live their everyday lives. Perhaps the individual's experience within these events will lead to changes in her everyday life, perhaps not.

Being part of a community or an ensemble doesn't mean giving up one's ability to plot one's own path or construct one's own narrative within a set of given circumstances, whether those circumstances require us to remain seated in our red chairs or to walk through a wood in which various characters appear to articulate their suffering or to join in the round dance.

\section{FIVE}

It is the 'blurring of the boundary between those who act and those who look' that is the meaning of emancipation, according to Rancière (2011: 19). It could be argued that this is exactly what theatre has been experimenting with for the past century. Different ensembles and practitioners have experimented with different kinds of participation and made different demands on the spectator/ participant, whether they are invited to join in a dance with Núñez and the Taller or to enact a potential solution to a social problem in the work of Augusto Boal.

Grotowski (1995) distinguished between Art as Presentation and Art as Vehicle. The former is the way in which we normally think of art - as something that takes shape in the perception of the spectator - whereas the latter emphasizes the experience of the 'doer' (1995: 120). Grotowski's emphasis from the mid-1970s onwards was on the doers, whether there were external witnesses to the action or not. This emphasis on doers runs 
throughout the archipelago of studios and workshops, tallers and laboratories that are dotted around the globe.

At least some of the Taller de Investigación Teatrals performance events can be seen as a hybrid of the Theatre of Presentation and the Theatre as Vehicle. For example, in Cura de espantos, the audience begin as participants but there is a sense in which they are not agents. Middleton mentions the 'monitors' whose task it is to 'construct and manage the participants' experience' (p. 173 above).

The participants are invited to step into the skeleton boat, place a tube of tissue over their heads so that they are effectively blindfolded and move with the boat into the wood where the tissue tube is removed, and then they are guided around the woods to witness four solo performances by figures who tell their stories of suffering. Up to this point the participants have made a decision to join in but their choices from that point are quite limited in terms of action. There is a clear set of actions that they are invited to carry out. Even the moment where the participants are given time for silent contemplation, after the encounter with the four figures, could be seen as directed action rather than self-initiated action. But they aren't compelled to stand in silent contemplation, it is an invitation rather than an instruction, and they have the possibility of doing something else. This moment of contemplation opens up a new possibility between the idea of the active and passive spectator and points towards a contemplative theatre.

\section{REFERENCES}

Artaud, Antonin (1958) The Theater and its Double (Trans. Mary Caroline Richards), New York: Grove Press.

Chemi, Tatiana (2018) A Theatre Laboratory Approach to Pedagogy and Creativity, Basingstoke: Palgrave Macmillan.

Gawboy, Anna (2015) 'The Mysterium' programme note for Scriabin in the Himalayas, Ladakh. http://www.scriabininthehimalayas.com/about accessed 11th October 2018 
Gerould, Daniel (1977) 'Sologub and the Theatre' in The Drama Review 21 (4) pp.79--84

Grotowski, Jerzy (2002) Towards A Poor Theatre, London: Methuen.

Grotowski, Jerzy (1995) 'From Theatre Company to Art as Vehicle' in Richards, Thomas, At Work with Grotowski on Physical Actions, London: Routledge, pp.115-35.

Machon, Josephine (2013) Immersive Theatres: Intimacy and Immediacy in Contemporary Performance, Basingstoke: Palgrave Macmillan.

Maffie, James (n.d) ‘Aztec Philosophy', The Internet Encyclopedia of Philosophy, ISSN 2161-0002, http://www.iep.utm.edu/, 11 $1^{\text {th }}$ June 2018.

Middleton, Deborah \& Núñez, Nicolás (2018) 'Immersive Awareness' in Theatre, Dance and Performance Training, 9:2, 217 - 233.

Morris, Eilon (2017) Rhythm in Acting and Performance: Embodied Approaches and Understandings, London: Bloomsbury Methuen.

Needleman, Jacob and Baker, George (eds.) (1998) Gurdjieff: Essays and Reflections on the Man and his Teaching, New York NY: Continuum.

Needleman, Jacob (1998) 'Gurdjieff in the Modern World', in Needleman and Baker (eds.) (1998) pp. 70-85.

Nietzsche, Friedrich (2000) The Birth of Tragedy (translated with an introduction by Douglas Smith), Oxford: OUP.

Rancière, Jacques (2011) The Emancipated Spectator, London: Verso Books.

Richards, Thomas (1995) At Work with Grotowski on Physical Actions, London: Routledge.

Schino, Mirella (2009) Alchemists of the Stage: Theatre Laboratories in Europe, Holstebrö: Icarus Publishing.

Slowiak, James and Cuesta, Jairo (2018) Jerzy Grotowski (reissue), London: Routledge.

Sologub, Fyodor (1977) 'The Theatre of One Will', (trans. Daniel Gerould) The Drama Review 21(4) pp. 85-99. 
Stanislavski, Konstantin (2008) My Life in Art, London: Routledge.

Strindberg, August (1979) Inferno and From an Occult Diary (trans. Mary Sandbach), Harmondsworth: Penguin)

Yarrow, Ralph et al. (2007) Sacred Theatre, Bristol: Intellect Books. 